University of Wollongong

Research Online

Faculty of Law, Humanities and the Arts Papers (Archive)

Faculty of Arts, Social Sciences \& Humanities

$1-1-2014$

Shame and the anti-suffragist in Britain and Ireland: drawing women back into the fold?

Sharon Crozier-De Rosa

University of Wollongong, sharoncd@uow.edu.au

Follow this and additional works at: https://ro.uow.edu.au/lhapapers

Part of the Arts and Humanities Commons, and the Law Commons

Research Online is the open access institutional repository for the University of Wollongong. For further information contact the UOW Library: research-pubs@uow.edu.au 


\title{
Shame and the anti-suffragist in Britain and Ireland: drawing women back into the fold?
}

\begin{abstract}
Shame has been heavily relied on as a political tool in the modern world and yet it is still a much underhistoricised emotion. Using the examples of early twentieth-century Britain and Ireland, I examine how women opposed to the campaign for female suffrage used shame instrumentally in their writing.

Exploring the versatility of this political device, I find that shame was used with the oppositional intentions of binding and excluding. Whereas British conservatives used it to protect an already well-established imagined community of good imperial women, Irish radicals drew on it to invite women to take part in the construction of a new nationalist sisterhood. This paper further problematizes claims that as an emotion that plays on a sense of the communal, shame has had no place in a highly individualistic modern world.
\end{abstract}

\section{Keywords}

back, into, fold, anti, britain, shame, suffragist, ireland, drawing, women

\section{Disciplines}

Arts and Humanities | Law

\section{Publication Details}

Crozier-De Rosa, S. (2014). Shame and the anti-suffragist in Britain and Ireland: drawing women back into the fold?. Australian Journal of Politics and History, 60 (3), 346-359. 
For: Australian Journal of Politics and History, Vol. 60, No. 3, 2014, pp. 346-359

'Shame and the Anti-Suffragist in Britain and Ireland: Drawing women back into the fold?’

Sharon Crozier-De Rosa

\begin{abstract}
Shame has been heavily relied on as a political tool in the modern world and yet it is still a much under-historicised emotion. Using the examples of early twentieth-century Britain and Ireland, I examine how women opposed to the campaign for female suffrage used shame instrumentally in their writing. Exploring the versatility of this political device, I find that shame was used with the oppositional intentions of binding and excluding. Whereas British conservatives used it to protect an already well-established imagined community of good imperial women, Irish radicals drew on it to invite women to take part in the construction of a new nationalist sisterhood. This paper further problematizes claims that as an emotion that plays on a sense of the communal, shame has had no place in a highly individualistic modern world.
\end{abstract}




\section{Shame and the Anti-Suffragist in Britain and Ireland: Drawing women back into the} fold ${ }^{1}$

\section{Introduction}

The use of militant tactics by women in early twentieth-century British and Irish suffrage campaigns raised questions about the place of emotions in the political realm. Many lamented the incursion of what they viewed as "hysteria" into the otherwise rational realm of national politics. $^{2}$ Nationalist, imperialist and gendered anxieties were mobilised by anti-suffragists who believed that the only appropriate emotion for women who dared to campaign for the vote was shame. Models of "good” national womanhood were invoked and attempts were made to impose shame upon those women who transgressed these models by campaigning for the franchise. In this article, I explore these attempts at shaming by drawing on two women's periodicals: one a conservative voice for the formal anti-suffrage movement in the British metropole; and, the other a radical nationalist women's paper in anti-colonial Ireland. The political aspirations of these two groups of women writers and activists were radically diverse, but they were connected by virtue of their opposition to allowing women to vote in an imperial parliament. They were also connected by their use of shame to construct or defend "good" communities of womanhood in line with their respective national narratives.

\footnotetext{
${ }^{1}$ I would like to thank Mark Seymour, Julia Martinez, Frances Steel, the anonymous reviewers and the organisers of and participants in the 2013 AAEH conference in Wellington for their very valuable comments on earlier drafts of this paper.

${ }^{2}$ For example, it was stated in the moderately feminist Irish periodical, The Lady of the House, that "hysteria has no place in political life”. Yet, the more radical feminist periodical, The Irish Citizen, declared emotion to have a place in all forms of life including politics. See The Lady of the House, "What do the Suffragettes Deserve?” 15 January, 1910, p. 15; and, The Irish Citizen, “The Populace Mind.” Vol. 1, 4 (June 1912), p. 27.
} 


\section{Emotions, Shame and Politics}

History is undergoing an "emotional turn,” if the recent proliferation of research centres and outpouring of academic publications is anything to go by. ${ }^{3}$ Whether beginning with Lucien Febvre’s 1940s call for an investigation of the emotions in their historical context or with those of later twentieth-century scholars like Bernard Bailyn, Theodore Zeldin and Carol and Peter Stearns, this expanding field of research has embraced a diverse range of histories, from the historiographical to the examination of discrete emotions such as fear and love. ${ }^{4}$ Shame has also been investigated. Recent research in past accounts of shame has produced a growing body of work that has served to historicise the emotion: from explorations of its mobilisation with respect to questions of crime and morality, to studies of family relations, intellectual disabilities, eugenics and changing emotional standards, to gender and the body in political protest, to national consciousness and the 'stains' of the past, including indigenous dispossession in New Zealand and the Great Famine in Ireland. ${ }^{5}$ Still, this sweeping range of usage means that there is much room for further historicisation of this emotion.

\footnotetext{
${ }^{3}$ See introductory remarks in Frank Biess, Alon Confino, Ute Frevert, Uffa Jensen, Lyndal Roper and Daniela Saxer, Forum: 'History of Emotions', German History, Vol. 28, 1 (2010), pp. 67-80. See also Jan Plamper, 'The History of Emotions: An Interview with William Reddy, Barbara Rosenwein, and Peter Stearns', History and Theory, Vol. 49 (May 2010), pp. 237-265, p. 237.

${ }^{4}$ See, for example, Lucien Febvre 'Sensibility and History: How to Reconstitute the Emotional Life of the Past', in Lucien Febvre, A New Kind of History and Other Essays, Peter Burke (ed.), transl. K. Folca, (New York, 1973); Bernard Bailyn, 'The Challenge of Modern Historiography', American Historical Review, Vol. 87, 1 (1982), pp. 1-24; Theodore Zeldin, 'Personal History and the History of the Emotions', Journal of Social History, Vol. 15 (1982), pp. 339- 347; Peter N. Stearns and Carol Z. Stearns, 'Emotionology: Clarifying the History of Emotions and Emotional Standards,’ The American Historical Review, Vol. 90, 4 (1985), pp. 813836; Barbara H. Rosenwein, 'Worrying about Emotions in History’, American Historical Review, (June 2002), pp. 821-845; William Reddy, The Navigation of Feeling: A Framework for the History of Emotions (Cambridge, 2001); Joanna Bourke, Fear: A Cultural History (London, 2005); Peter Stearns, American Fear: The Causes and Consequences of High Anxiety (New York, 2006); and, Martha Tomhave Blauvelt's The Work of the Heart: Young Women and Emotion, 1780-1830 (Charlottesville, 2007).

${ }^{5}$ See, for example, David Nash and Anne-Marie Kilday, Cultures of Shame: Exploring Crime and Morality in Britain 1600-1900 (Basingstoke, 2010); Deborah Cohen, Family Secrets: Shame and Privacy in Modern Britain (Oxford, 2013); Begoña Aretxaga, Shattering Silence: Women, Nationalism, and Political Subjectivity in Northern Ireland (Princeton, New Jersey, 1997); Barbara Brookes, 'Shame and its Histories in the Twentieth Century, Journal of New Zealand Studies, 9 (2010), pp. 37-54; and, Vincent Comerford, 'Grievance, Scourge or
} 
Reasons for feeling shame change over time but the basis of this emotion remains constant. Shame is and was about belonging and identity. It was used as a political tool because it played on fears about social exclusion. As scholars from Norbert Elias in the mid-twentieth century to Thomas Scheff, John Holland and Richard Shweder in the late twentieth and early twenty-first centuries have argued, this emotion is about a fear of being judged defective; a "fear of social degradation”. ${ }^{6}$ As such, it has been considered the "social emotion" and the "master emotion" for, as Scheff argues, shame is always present because that fear of being judged, found defective and subsequent conferral of loss of status is always anticipated. ${ }^{7}$ It has been used to confirm what it means to be a "good" member of a group but understandings of "good" are socially, politically, culturally and historically specific. As an emotion that links internal anxieties and values to external influences and standards, then, shame is historically contingent. The external anxieties and values it feeds on change across time and so shame offers historians a pathway into the social and political preoccupations of past societies.

Whatever the concerns of some at the time or historians since, emotions like shame did play a pivotal role in political affairs. ${ }^{8}$ In many instances, shame has been a versatile component of the "moral, cognitive, and emotional package of attitudes” that forms the successful political

Shame? The Complexity of Attitudes to Ireland's Great Famine', in Christian Noack, Lindsay Janssen and Vincent Comerford (eds.), Holodomor and Gorta Mór: Histories, Memories and Representations of Famine in Ukraine and Ireland (London, 2012).

${ }^{6}$ See Norbert Elias, The Civilizing Process: The History of Manners and State Formation and Civilization, Transl. by Edmund Jephcott (Oxford, UK, and Cambridge, USA, 1994 [1939]), p. 492; Thomas J. Scheff, "Shame and the Social Bond: A Sociological Theory", Sociological Theory, Vol. 18, 1 (March 2000), pp. 84-99, p.97; John Hollander, "Honor Dishonorable: Shameful Shame”, Social Research, Vol. 70, 4 (Winter 2003), pp. 1061-1074; and, Richard A. Shweder, "Toward a Deep Cultural Psychology of Shame”, Social Research, Vol. 70, 4 (Winter 2003), pp. 1109-1130, p. 1116.

${ }^{7}$ Thomas J. Scheff, “Shame in Self and Society”, Symbolic Interaction, Vol. 26, 2 (2003), pp. 239-262, p. 256.

${ }^{8}$ The editors of Passionate Politics have recently argued that there has been a seeming reluctance to admit the centrality of emotions in the political realm and 'understand both the intersecting reason and passion of political life’. Jeff Goodwin, James Jasper and Francesca Polletta, “Why Emotions Matter”, in Jeff Goodwin, James Jasper and Francesca Polletta (eds.), Passionate Politics: Emotions and Social Movements (Chicago, 2001), pp.1-24, p. 5. 
activist's toolkit. ${ }^{9}$ Activists have used shame to variously bind members of a particular group closer together, to confirm the exclusion of outsiders, or to draw those outsiders into the fold. Some today continue to believe that a healthy dose of shame has the power to inspire political action for the good of the community (in the case of philosopher Michael L. Morgan's work, to motivate people to work towards eliminating genocide from the modern world). ${ }^{10}$ Yet, relying on shame to achieve political ends has its limitations. For, as feminist theorist Jill Locke has pointed out, shaming only works as a political tool if the target has the "ability to engage in shameful self-assessment". ${ }^{11}$ Early twentieth-century "shaming” of unwomanly radical feminists or disloyal female nationalists, for example, was only successful if those unwomanly or disloyal women valued the connections they had with the community of "good" national womanhood to which they were supposed to belong. Early twentieth-century British and Irish female activists of politically diverse backgrounds, united by a common desire to prevent women obtaining the vote in British parliament, used shame, but whether to draw into the fold or to confirm exclusion is a matter for further exploration.

\section{Looking Backwards: Conservative Britain, the threat of the New Woman and the}

\section{complications of imperial decline.}

During the late nineteenth and early twentieth centuries, when the British Empire was at its height, England articulated an understanding of itself within this vast imperial framework: as the global standard bearer of civilisation, modernity and progress. ${ }^{12}$ However, even at the height of empire, this narrative of progress and respectability was not secure. The metropole

\footnotetext{
${ }^{9}$ Goodwin, Jasper and Polletta, "Why Emotions Matter”, p. 16.

${ }^{10}$ Michael L. Morgan, On Shame (New York and London, 2008), for example, p. 43.

11 Jill Locke, "Shame and the Future of Feminism”, Hypatia, Vol. 22, 4 (Fall 2007), pp. 146-162, p. 156.

12 Bernard Porter, The Absent-Minded Imperialists: Empire, Society, and Culture in Britain (Oxford, 2004), pp. 243-244; Shula Marks, "History, the Nation and Empire: Sniping from the Periphery”, History Workshop Journal, Vol. 29, 1, (1990), pp. 111-119, pp. 115-117; and, Krishan Kumar, "Nation and Empire: English and British National Identity in Comparative Perspective”, Theory and Society, Vol. 29 (2000), pp. 575-608, pp. 575 and 591.
} 
was riddled with anxieties about national and imperial decline in an age of political turbulence. ${ }^{13}$ Women agitating for civil rights on the domestic front only added to those worries. How could the metropole transport and transplant British notions of middle-class respectability - those on which the empire depended - if its own women were unsettling these very values? Such women, as renowned scholar Anne McClintock has argued, were denying the metaphorical role of women as the conservative repository of the national archaic, the living archive of national values. ${ }^{14}$ By agitating for what seemed to be the right to ape or even supplant the British man's role as “the forward-thrusting agency of national progress" - by wanting to go forward rather than remain still - these transgressive women challenged a national narrative that positioned women as "inherently atavistic". ${ }^{15}$ Not surprisingly, then, feminist agitation in the imperial centre provoked a very passionate, even violent exchange between those keen for reform and those protective of the status quo.

Shame was used as a political tool to navigate these national anxieties and instil a sense of calm. It was also used by women to defend a much cherished imagined community of "good” British womanhood. ${ }^{16}$ This use of shame was glaringly apparent in articles printed in the Anti-Suffrage Review [the Review] (1908-1918), the official organ of the National League for Opposing Woman Suffrage in Britain.

\footnotetext{
${ }^{13}$ Bradley Deane, “Imperial Barbarians: Primitive Masculinity in Lost World Fiction”, Victorian Literature and Culture, Vol. 38, (2008), pp. 205-225, p. 213. See also Andrew Thompson, The Empire Strikes Back: The Impact of Imperialism on Britain from the Mid-Nineteenth Century (Harlow, UK, 2005) for an extended discussion of what the empire meant to various sections in England including the elites, middle- and lower middle class and the working class.

${ }^{14}$ Anne McClintock, "No Longer in a Future Heaven: Gender, Race and Nationalism”, in Anne McClintock, Aamir Mufti and Ella Shohat (eds.), Dangerous Liaisons: Gender, Nation and Postcolonial Perspectives (Minneapolis, 1997), pp. 89-112.

${ }^{15}$ McClintock, "No longer in a future heaven”, p. 93.

${ }^{16}$ I have written elsewhere on the prolific use of shame by British bestselling novelist, Marie Corelli, to rebuke campaigning feminists for their dangerously unwomanly behaviour. See Sharon Crozier-De Rosa, 'Shame, the New Woman and Marie Corelli in Fin-de-Siècle Britain’ in David Lemmings and Ann Brooks (eds.), Emotions and Social Change: Historical and Sociological Perspectives (New York, 2014), pp. 252-268.
} 
Before discussing the use of shame in the Review, I want first to chart, necessarily briefly, the movements for and against female suffrage in Britain at the time. The campaign for the female vote in England has a long history. However, it was only in 1905, when the suffrage movement began to adopt strategies of Suffragette militancy, that public attention really became focussed on it. As June Purvis writes, it was only the "confrontational, assertive and 'unladylike' tactics” of the new "militant” strategies of the recently formed Women’s Social and Political Union (WSPU) (formed in 1903 by Emmeline Pankhurst and her daughter, Christabel Pankhurst who were dissatisfied with the lack of progress of the National Union of Women's Suffrage Societies (NUWSS)) that forced the woman's suffrage issue into the limelight. ${ }^{17}$ The violent and therefore "unladylike” nature of Suffragette tactics only escalated. From 1905 to 1912, the campaign took the form of heckling politicians, noisily disrupting political meetings, and a willingness to go to prison rather than paying fines for “unruly” behaviour. From 1912 until their cessation with the beginning of the Great War in 1914, Suffragettes moved on to more violent and often illegal forms of activity such as mass window-breaking raids, vandalising post boxes, attacking public property, including setting fire to buildings, and going on hunger strike. ${ }^{18}$ It was the increasing intensity of the militant suffrage campaign that motivated anti-suffragists in England, Scotland, Wales and Ireland to organise themselves more formally, leading to the establishment of the Women's National Anti-Suffrage League in 1908 which was later to merge with the men's branch of the antisuffrage movement in 1910, culminating in the National League for Opposing Woman Suffrage (1910-1918).

17 June Purvis, 'Fighting the Double Moral Standard in Edwardian Britain: Suffragette militancy, Sexuality and the Nation in the Writings of the Early Twentieth-Century British Feminist Christabel Pankhurst', in Francisca de Haan, Margaret Allen, June Purvis and Krassimira Dasklova (eds.), Women's Activism: Global Perspectives from the 1890s to the Present (New York, 2013), pp. 121-135, p. 121.

${ }^{18}$ June Purvis, 'Fighting the Double Moral Standard in Edwardian Britain', p. 121. 
In 1978, when much was being written on the suffrage movement, Brian Harrison warned historians against ridiculing the efforts of the anti-suffrage movement as "misguided and unimportant” or dismissing their ideals on the basis of their eventual failure thereby consigning this unsuccessful movement to "history’s rubbish-heap”. For those who did seem inclined to pay attention to the anti-suffrage movement, his writing contained further cautions against viewing this conservative mindset as singular, shallow or uncomplicated. ${ }^{19}$ However, it was from the 1990s that work on the complexities of conservative women's organisations, including those engaged in anti-suffrage activities, began to expand. In challenging simple applications of the label "anti-feminist" to women involved in anti-suffrage and other related campaigns, the insightful work of scholars such as Lucy Delap, Valerie Sanders, Julia Bush and David Thackeray broadened current understandings of the sheer diversity of late Victorian and Edwardian conceptions of female citizenship from the point of view of women writers and activists. $^{20}$ As Julia Bush points out in her 2007 book, Women Against the Vote: Female Suffragism in Britain, it was the highly respected and publicly renowned women of this crusade against the female franchise - including president of the Women’s League, Lady Jersey, the novelist Mary Ward (Mrs Humphry Ward), imperialist writer and traveller Gertrude Bell, writer and reformer Ethel Bertha Harrison, and daughter of Joseph Chamberlain, Beatrice Chamberlain - who conducted many of the League for Opposing Woman Suffrage activities and who also contributed to the editing and writing of the AntiSuffrage Review.

\footnotetext{
${ }^{19}$ See Brian Harrison, Separate Spheres: The Opposition to Women's Suffrage in Britain (London, 1978), pp. 13-24.

${ }^{20}$ See Valeria Sanders, Eve's Renegades: Victorian Anti-Feminist Women Novelists (Basingstoke, 1996); Julia Bush, 'British Women's Anti-Suffragism and the Forward Policy, 1908-14', Women's History Review, Vol. 11, 3, (2002), pp. 431-454; Lucy Delap, 'Feminist and Anti-Feminist Encounters in Edwardian Britain’, Historical Research, vol. 78, 201 (2005), pp. 377-399; Julia Bush, Women Against the Vote: Female Suffragism in Britain (Oxford, 2007); and, David Thackeray, 'Home and Politics: Women and Conservatism Activism in Early Twentieth-Century Britain’, Journal of British Studies, Vol. 49, 4 (2010), pp. 826-848.
} 
As the official journal of the Women's National Anti-Suffrage League and then the National League for Opposing Woman Suffrage, the Review had two overarching aims: one was to inspire and gather wide public support for opposition to woman suffrage through extraparliamentary propaganda; the other was to "exert direct pressure on parliamentary decisionmakers”. ${ }^{21}$ In the period preceding the war at least, male members of the League - including Lord Curzon and Lord Cromer - preferred pursuing a single-minded campaign to persuade male politicians of the dangers of female suffrage, while leading female members - such as Lady Jersey and Mary Ward - favoured using public appearances, speeches, articles in the popular press and in the Review to garner mass public support for their cause and hopefully stimulate debate about the wider "woman question". ${ }^{22}$ Despite the different approaches, what male and female tactics had in common was firm dedication to the belief that granting female suffrage would only have dire consequences for the English nation and, by extension, the British Empire. That the League boasted 42,000 subscribing members and 15,000 adherents by 1914 (drawn from branches in England, Wales and Ireland and the affiliated Scottish League for Opposing Woman Suffrage) indicated that the Review had a potentially wide readership among like-minded opponents of the female franchise. ${ }^{23}$

The pages of the Review were frequently home to long passages that, ostensibly, attempted to invoke a feeling of shame among active and militant women in the imperial metropole. However, the problem with this approach is that apart from a few letters in the correspondence pages from members of the opposing movement, it is highly likely that the intended audience of this publication were like-minded anti-suffragists, all drawn from the community of good, white, national and imperial women. Moreover, the paper's use of

\footnotetext{
${ }^{21}$ Julia Bush, 'National League for Opposing Woman Suffrage (act. 1910-1918)', Oxford Dictionary of National Biography, online edn, Oxford University Press, May 2008, http://www.oxforddnb.com/view/theme/92492, accessed 13 Nov 2011.

${ }^{22}$ Bush, 'National League for Opposing Woman Suffrage'.

${ }^{23}$ Bush, 'National League for Opposing Woman Suffrage'.
} 
shame was much more vitriolic and exclusionary than it was encouraging or embracing and so there is little evidence that the League thought that the women they were targeting would honour a social bond with British conservative women to the point that they would engage in the act of shameful self-assessment. And yet, this shaming of transgressive women was rife over the lifetime of the journal. So why was shame there if it was not to shame transgressive women into adjusting their behaviour, thereby drawing them back into the fold of "true" womanhood? I suggest the answer is that shame in these texts served to tell a story. It served to show where shame was not present in British womanhood and to point out where it should have been present. It confirmed that there were those "good" and "true” women who did understand the appropriateness of a womanly sense of shame. It is much more likely, then, that the Review used shame to confirm the existence of a faultline that divided the community of "true" English womanhood from that of its transgressive other.

From its inception, the Review declared that it was opposed to women gaining the right to vote because voting “involves a kind of activity and responsibility for woman which is not compatible with her nature, and with her proper tasks in the world”. Woman was not built for "the rough and ready machinery of party politics”. Besides, women did not need to prove themselves men's equal in citizenry; they already were equal. They were citizens no less than men but in "a more ideal and spiritual sense" than those men who built up the State and who must now protect it with their physical strength. Women had made enough advancement over the past fifty years without the vote. ${ }^{24}$ They did not need to move anymore. To force them to be something they were not - to force them to act contrary to their natures by compelling them to ape man's behaviours and duties - was shameful.

\footnotetext{
${ }^{24}$ The Anti-Suffrage Review, (London), 1, December 1908, p. 1.
} 
That those who had been campaigning for the female franchise throughout the late nineteenth and early twentieth century were ignoring the true nature of the nation's women was irresponsible. But, there was perhaps the chance that these people, deluded as they were about the make-up of English femininity, could be re-educated and reformed. However, by 1908, campaigning feminists went too far, thereby drawing a line between themselves and the community of respectable women. By this time, the image of the militant suffragist was a familiar one. Conservative women were no longer simply facing suffragists; their new opponent was the Suffragette. The National League for Opposing Woman Suffrage, the Review explained, was driven to establish itself as an organised body because of the "shock of repulsion" and "wave of angry laughter” rocking England due to the recent, much publicised actions of militant suffragists there. ${ }^{25}$ "Have not the spectacles of the last few weeks", the paper asked, "shown conclusively that women are not fit for the ordinary struggle of politics, and are degraded by it?” All militant feminists had done was to render "the calm and practicable discussion of great questions impossible; a feeling and antagonism disastrous to women, disastrous to England”. ${ }^{26}$

The Suffragette had attacked the very essence of English womanhood. But, Suffragettes had proved themselves even more dangerous in that they also attacked England's reputation and its place at the centre of the civilised world. Militant feminists had joined England's enemies - the Boers, Sudanese, Irish, and Afghanis - in attacking the very fabric of the Empire. If these transgressive women were to prove successful - if they were to gain the right to vote because of their unwomanly acts of violence - then England would be weakened "in the eyes of the civilised world”. Such an outcome would, the Review declared, "fatally diminish those stories of English sanity, of English political wisdom, based on political experience, which

\footnotetext{
${ }^{25}$ The Anti-Suffrage Review, (London), 1, December 1908, p. 1.

${ }^{26}$ The Anti-Suffrage Review, (London), 1, December 1908, p. 1.
} 
have gone - through all vicissitude, failure, and error - to the making of England, and the building up of the Empire”. ${ }^{27}$ Britain’s enemies were not only without, they were also within the nation's borders. Worse still, they were the very beings who were supposed to protect the nation's sacredness, who were supposed to be its feminine guardians.

In this context, then, shame was used passionately and consistently by the community of good women in order to protect what they saw as a well-established and precious identity. But, what happens when the collective identity of a group - female or national - is considered to be in the process of construction or reconstruction? Ireland, with its simultaneous moves for feminist and nationalist liberation, suggests itself as a good case study for exploration of this question.

\section{Looking Forwards: Ireland, Nationalism and the Potential Woman Citizen}

Many in Ireland too were campaigning for the female franchise. Activists such as the Dublin-based Quaker Anna Haslam and Belfast Presbyterian Isabella Tod had been campaigning for the vote in Ireland since the 1870s. Nationalist and unionist women formed part of the same movement for women's emancipation, although until the twentieth century, Protestants and unionist women formed the majority of active suffragists. ${ }^{28}$ By the end of the nineteenth century, these women had made some headway with women gaining eligibility for election as Poor Law Guardians in 1896, for example. ${ }^{29}$ But it was with the formation of the Irish Women’s Franchise League in 1908 that the Irish female suffrage campaign entered into

\footnotetext{
${ }^{27}$ The Anti-Suffrage Review, (London), 1, December 1908, p. 2.

${ }^{28}$ Mary Cullen, 'Feminism, Citizenship and Suffrage: A Long Dialogue', in Louise Ryan and Margaret Ward (eds.), Irish Women and the Vote: Becoming Citizens (Dublin, 2007), pp. 1-20, p. 12. For more on Irish emancipation campaigns generally see Mary Cullen, 'The Potential of Gender History', in Maryann Gialanella Valiulis (ed.), Gender and Power in Irish History (Dublin, 2009), pp. 18-38.

${ }^{29}$ Cullen, 'Feminism, Citizenship and Suffrage', pp. 10-11.
} 
a renewed, much reinvigorated phase. ${ }^{30}$ Not only were many in Ireland campaigning for the vote, but by 1912 the Irish suffrage campaign had also entered into a militant phase. And so, in the eyes of British and Irish anti-suffragists, these female activists were perpetrators of the same transgressive unwomanly behaviour as militants in Britain. Like their British counterparts, therefore, they were not immune to the more general accusations of selfishness and shamelessness levelled at campaigning feminists. The difference with Ireland, of course, was its positioning on the imperial spectrum and its early twentieth-century reactions to this positioning, reactions that caused friction and eventual separation between nationalist and unionist suffrage activists.

Ireland was England's oldest imperial possession and since the 1800 Act of Union it was either an equal partner in the United Kingdom of Great Britain and Ireland or, in the eyes of Irish nationalists certainly, an inferior member of the Kingdom and a continued colonial possession. So, at a time when the whole island of Ireland was still an integral part of the British Empire, pro-British Irish anti-suffragists had formed a Dublin-based branch of the British National League for Opposing Woman Suffrage. This establishment of a Dublin branch meant that the unionist anti-suffrage movement in Ireland had intrinsic links with its sister branches in England and Wales and its affiliated association in Scotland and it had a shared vehicle for voicing its concerns in the League’s official organ, the Anti-Suffrage Review. As an extension of the League, this Irish branch opposed moves for the female franchise in Britain on the basis that it threatened the stability of the union and the empire. This amalgamation of Irish unionist and British objectives was also reflected in Britain where, as Margaret Ward argues, British suffragists and anti-suffragists alike did not factor

\footnotetext{
${ }^{30}$ Maria Luddy, 'Introduction', in Louise Ryan and Margaret Ward (eds.), Irish Women and the Vote: Becoming Citizens (Dublin, 2007), pp. xiii-xxii, p. xiii.
} 
into their campaign the intricacies of the Irish national context and instead promoted combined movements that were dismissive of national differences. ${ }^{31}$

The complex dynamics of unionist-nationalist politics in Ireland rendered the face of antisuffragism there even more convoluted than in Britain. For Irish anti-suffragism, of course, was not confined to the unionist side of politics. Rather, there were staunch antis in the nationalist community. Leader of the Irish Parliamentary Party, John Redmond, for example, was notoriously opposed to the female franchise. But the reasons for opposing the female vote among nationalists were complicated. In the early decades of the twentieth century, there was a renewed push for national recognition in Ireland. On one side of the movement, there was the previously mentioned moderately nationalist Irish Parliamentary Party led by Redmond who wanted a Home-based parliament in Ireland; a commonwealth parliament still subservient to the Westminster imperial parliament. Importantly, this was the party that held the balance of power in the Westminster parliament and that - because of its dealings with the Liberal Party over the granting of Home Rule in Ireland - had been the decisive factor in preventing the almost assured success of the Conciliation Bill in 1912 that would have granted female franchise in Britain. On the other side of the nationalist debate there were the radicals who wanted complete separation from Britain; an independent Ireland free of all imperial ties, equal or subservient. And these activists were represented in the main by Sinn Féin, whose aspirations for complete autonomy were clearly present in its title, translated from the Gaelic as "We, Ourselves”.

\footnotetext{
${ }^{31}$ Margaret Ward, “Conflicting Interests: The British and Irish Suffrage Movements”, Feminist Review, No. 50 (Summer 1995), pp. 127-147. This case is also made in Lucy Delap, Louise Ryan and Teresa Zackodnik, "SelfDetermination, Race, and Empire: Feminist Nationalists in Britain, Ireland and the United States, 1830s to World War One”, Women's Studies International Forum, Vol. 29, (2006), pp. 241-254.
} 
Prior to 1916 - when Irish politics became more radicalised after prominent members of all major Irish nationalist groups (the Irish Republican Brotherhood, Irish Volunteers and Irish Citizen’s Army) were executed by the British after a failed uprising - the face of women’s activism in Ireland was one of multiplicity. ${ }^{32}$ There were female activists who defined themselves as nationalist and did not agitate for women's rights independent of nationalist goals; women like the Protestant editors of The Shan Van Vocht (The Poor Old Woman), a Belfast based paper that did not mind advocating that women use their roles as mothers and homemakers to advance the nationalist cause. ${ }^{33}$ And, certainly there were the previously mentioned feminists who were loyal to the union with Britain and who played a pivotal role in Unionist politics of the time. But by the early twentieth century, a large proportion of Irish feminists were nationalist in outlook. And this community of nationalist feminist activists was further divided into two major camps: those supporting the more popular moderate Home Rulers, and the minority of more extreme separatists supporting and being supported by Sinn Féin. ${ }^{34}$

Many of the Irish men who opposed the female franchise did so for a variety of reasons. There were those who were against this practise as a general principle (like many men and women in Britain). However, others opposed it because they prioritised nationalist imperatives. Many nationalist parliamentarians thought that inserting a clause for the female franchise into the Home Rule Bill they were trying to pass through British Parliament, for example, would just give those opposed to Irish Home Rule further reason for delaying its inception. Of course, many nationalist women also saw wisdom in delaying the introduction

\footnotetext{
${ }^{32}$ For more on the Easter Rising, see, for example, Fearghal McGarry, The Rising: Ireland: Easter 1916 (Oxford, 2010).

${ }^{33}$ For a detailed discussion of The Shan Van Vocht, see Karen Steele, Women, Press, and Politics during the Irish Revival (Syracuse, 2007), pp.27-65.

${ }^{34}$ For a detailed discussion on the differences of women's nationalism in Ireland, see Margaret Ward, Unmanageable Revolutionaries: Women and Irish Nationalism (London, 1983).
} 
of female suffrage until Home Rule had been secured. What is so interesting about the Irish context is that some of the most strident anti-suffragism in Ireland - seemingly paradoxically - emanates from these Irish nationalist feminist women. Despite their strong, almost oppositional ideological preferences, conservative British female imperialists and radical Irish nationalist women had at least their opposition to women getting the vote in British parliament in common, which provides an excellent opportunity for the exploration of transnational connections and ruptures.

There is no doubt that the relationship between Irish feminism and nationalism is a complex one. In the early 1990s, renowned scholar of Irish women’s history, Margaret Ward, issued a call for an integration of Irish feminist and Irish nationalist history. ${ }^{35}$ The colonial relationship between Britain and Ireland, Ward contended, had severe repercussions for the Irish suffrage movement. The intervention of British suffrage activists in the Irish suffrage movement, without any interest in the intricacies of the Irish situation, for example, worked against the establishment of a strong, united Irish suffrage movement and these details, Ward argued, needed to be factored into histories of feminism, not siloed. Since Ward's call, there has been an abundance of superb historical research into feminism and nationalism in Ireland. ${ }^{36}$ Some of this research has found that many of the complications and ambiguities inherent in the feminist-nationalist relationship went to the heart of group identity. As Cliona Murphy has argued, the debate among early twentieth-century Irish feminists regarding whether to prioritise suffragism or nationalism in effect drew on another larger decision and

\footnotetext{
${ }^{35}$ Margaret Ward, “Conflicting Interests”, pp. 127-147.

${ }^{36}$ See, for example, Cliona Murphy, “Suffragists and Nationalism in Early Twentieth-Century Ireland”, History of European Ideas, Vol. 16, 4-6 (1993), pp. 1009-1015; Louise Ryan, "Traditions and Double Moral Standards: The Irish Suffragists’ Critique of Nationalism”, Women's History Review, Vol. 14, 4, (1995), pp. 487-503, p. 490; and, Louise Ryan, "A Question of Loyalty: War, Nation, and Feminism in Early Twentieth Century Ireland”, Women's Studies International Forum, Vol. 20, 1, (1997), pp. 21-32. See also Jason Knirck, Women of the Dáil: Gender, Republicanism and the Anglo-Irish Treaty (Dublin, 2006), p. 12, who argues that decisions about whether to pursue nationalist or feminist goals first was not about the ultimate desirability of one over the other but about "timing and priority".
} 
that was whether to prioritise or conversely to ignore or even deny “part of one’s identity one’s nationality or one’s gender”, ${ }^{37}$ Nationalist feminists' use of shame as a tool for political reform, then, was intimately tied to this concept of identity; it was used to target contested notions of identity.

More than simply offering historians an insight into how these women attempted to navigate these contested and competing loyalties, an examination of the uses of shame in Irish women's political journals also allows us to view how these feminist nationalists (or nationalist feminists) tried to construct a new group identity that incorporated all loyalties and that was in line with a newly emerging Irish national narrative. In that way, and as Louise Ryan has repeatedly suggested, suffrage debates in early twentieth-century Ireland probably have more in common with countries that were similarly engaged in anti-imperialist struggles - places like India and the Philippines - where feminists also had to deal with questions posed by nationalism, than with those in other European countries. ${ }^{38}$

The complex and dynamic relationship between Irish nationalism and feminism was explored in a number of contemporary women's publications around the turn of the century including the previously mentioned The Shan Van Vocht. It was also the focal point of many articles in the Irish Citizen, a suffrage journal that emerged in 1912 in response to widening divisions among British and Irish suffragists because of an intensifying campaign for Home Rule which, of course, included the decision made by the Irish Parliamentary Party to oppose the passing of the 1912 Conciliation Bill and therefore the female franchise in Britain. ${ }^{39}$

\footnotetext{
${ }^{37}$ Murphy, "Suffragists and Nationalism”, p. 1010.

${ }^{38}$ Ryan, "Traditions and Double Moral Standards”, p. 490; and, for an extended discussion of this see Ryan, "A Question of Loyalty”, pp. 21-32.

${ }^{39}$ For recent works examining the women's press in Ireland around this time, see C. L. Innes, “'A Voice in Directing the Affairs of Ireland': L'Irlande Libre, The Shan Van Vocht and Bean na h-Eireann”, in Paul Hyland and Neil Sammells (eds.), Irish Writing: Exile and Subversion (Basingstoke, 1991), pp. 146-158; Louise Ryan,
} 
However, the periodical with which this article is most interested is Bean na hEireann [the Bean], translating as Woman of Ireland, which ran from 1908 to 1911 and which pronounced itself the first Irish nationalist-feminist paper. The Bean was the organ of Inghinidhe na hEireann (Daughters of Ireland), a radical nationalist, pro-militant women's group that was to later merge with Cumman na mBan, the women’s wing of the Irish Republican Army. Although earlier women's papers like L'Irlande libre, edited and largely written by Maud Gonne, and the previously mentioned The Shan Van Vocht, edited by Alice Milligan and Anna Johnson, were managed by nationalist women, they did not declare themselves “Nationalist Women's papers” as the Bean did. Indeed, through an editorial by Helena Moloney later in the journal's life, the Bean took upon itself the label of "the first and only Nationalist Woman's paper". ${ }^{40}$ It promoted itself as a paper advocating separatism, feminism and "the interest of Irishwomen generally" and, as Karen Steele explains, it "quickly developed into an important platform for advanced nationalist women seeking a voice in the growing liberation movements of nationalism, feminism and socialism”. ${ }^{41}$ Written mostly by women assuming strong Celtic personae, the paper also found room for commentary by male nationalists including Arthur Griffith, James Stephens and Bulmer Hobson. ${ }^{42}$

The Bean employed shame consistently but to varying ends. On the one hand, it used this emotional device to encourage Irishwomen into the fold of good nationalist women; and on

\footnotetext{
“The Irish Citizen, 1912-1920”, Saothar, Vol. 17 (1995), pp. 105-111; Steele, Women, Press and Politics; Sonja Tiernan, "Tabloid Sensationalism or Revolutionary Feminism? The First-Wave Feminist Movement in an Irish Women’s Periodical”, Irish Communications Review, Vol. 12 (2010), pp. 74-87; and, Brittany Columbus, "Bean na h-Éireann: Feminism and Nationalism in an Irish Journal, 1908-1911”, Voces Novae: Chapman University Historical Review, Vol. 1, 1 (2009).

${ }^{40}$ Innes, “"A Voice in Directing the Affairs of Ireland””, p. 146.

${ }^{41}$ Steele, Women, Press, and Politics, p. 109.

42 Steel, Women, Press, and Politics, p. 110. For a discussion of the complex nature of the so-called Celtic Revival - one feature of which was the mentioned adoption of Celtic personae - see, among others, Declan Kiberd, Inventing Ireland: The Literature of the Modern Nation (London, 1996) and Gregory Castle, Modernism and the Celtic Revival (Cambridge, 2001).
} 
the other, it found itself shaming those Irish women for needing any encouragement in the first place. Importantly - and of value for the purposes of this article - even as a selfproclaimed feminist paper, the Bean declared itself opposed to Irish women campaigning for the vote.

The differing motivations of women opposed to the female franchise in Britain and those opposed to it in Ireland were tied to the differing natures of the ideal community of womanhood in each state. In Britain, shame was used frequently by women who wanted above all else to protect what they considered to be a stable community with a stable identity: that of good, white, national and imperial women. In Ireland, nationalist women were actively trying to construct a new community of "good” Irish women. There was no stable identity to be protected for Ireland was in the midst of an intensifying campaign for national liberation, a nationalist process that involved the construction of a new imagined community. Shame was used to draw a protective line around an existing community of womanhood in Britain. In Ireland it was used to inspire women to join in the construction of a new community; one that was not only politically active for all the right reasons (nationalist and feminist) but that was also proud of both its ancient lineage and its avant garde perspective.

In the first place, in an article entitled "To Our Sisters", and in a tone that was initially less shaming than it was inviting and encouraging, Irishwomen were called on to abandon their present collective state of apathy: 
We Irishwomen must learn to throw off our present diffidence, and assume our natural position in Irish life, and men will soon have to frankly admit that it is only by working hand in hand that we can hope to make Ireland free. ${ }^{43}$

“To Our Sisters” continued: "Our raison d'etre [sic] is to awaken Irishwomen to their responsibilities and long neglected duties”. ${ }^{44}$ Irishwomen were part of an ethnic group that had recently lost its way. Ireland was a country that in the last few score years had lost its sense of itself as a historic nation. In an appeal to all who considered themselves Irish women in particular judging by the article’s title, "Irishwomen’s Duty” - one writer declared: "We of this generation, if we are worthy of our race, must do our share towards regaining...[the country’s sense of itself as a nation]”. ${ }^{45}$ Irishwomen were to help construct a new national identity and a newly imagined sisterhood of Irishwomen by reconnecting with their ancestors; heroines of old who were not afraid of direct action or militancy. In the past, “Irishwomen’s Duty” continued, women were not "the least among our patriots”. Back then, Irishwomen had assumed the role of protector of all that stirred "the people to a remembrance of their common kinship”. ${ }^{46}$ It was up to women of the present generation to get back in touch with that heritage. Only by moulding their individual memories into a collective consciousness - one that traced its origins back to the women of the ancient order - could a community of good nationalist Irish women once again be formed. Like Irish nationalist men, women writing for the Bean attempted to construct an empowering narrative of revival and resurgence. They created a story of nationalism and self-determination that was

\footnotetext{
${ }^{43}$ Bean na hEireann, “To Our Sisters”, Vol. 1, 3 January, 1909, p. 1.

${ }^{44}$ Bean na hEireann, “To Our Sisters”, Vol. 1, 3 January, 1909, p. 1.

${ }^{45}$ Bean na hEireann, “Irishwomen's Duty” by LaSairfíona, Vol. 1, 3 January, 1909, p. 10.

${ }^{46}$ Bean na hEireann, “Irishwomen’s Duty” by LaSairfíona, Vol. 1, 3 January, 1909, p. 10.
} 
nourished by a glorious past of national autonomy - this time a female past - but that simultaneously offered a vision for the future. ${ }^{47}$

Still, despite examples of more positive, more inspirational sentiments, the ever pervading sense that Irishwomen were not up to the task of reinvigorating the nationalist movement coloured much of the Bean's commentary. A sense of frustration, disillusion and despair crept into many of the subsequent articles, leading to increasing attempts to invoke a patriotic sense of womanly shame. Indeed, even within the previously mentioned article, “Irishwomen's Duty”, the author resorted to a technique of shaming, declaring:

It has long been a reproach to Irish women of this generation that they are, to a very great extent, out of touch with the tradition of Irish Nationalism, and are more emphatically strangers in their own land than even their brothers. ${ }^{48}$

This reproach was more than simply an individualised form of reprimand, however, for it carried with it an intention to play on notions of national and gendered belonging to mobilise women for the good of the collective. It was women's responsibility to inspire their men to take up the nationalist cause. That many of them could not perform this feminine duty because they were even more out of touch with their heritage than apathetic men was to their shame. How could they be the repositories of the national archaic, to hark back to Anne McClintock's theorising, if they did not know or feel their past? But more than simply performing their metaphorical duties as the nation's moral guardians - as men's muse - the Bean called on Irishwomen to step up and step out and actively engage in the nationalist movement. They were even called on to take up arms if necessary.

\footnotetext{
${ }^{47}$ For more on the use of myths to construct new national identities see, for example, John Hutchinson, "Myth Against Myth: The Nation as Ethnic Overlay”, Nations and Nationalism, Vol. 10, 1/2, (2004), pp. 109-123.

${ }^{48}$ Bean na hEireann, “Irishwomen’s Duty” by LaSairfíona, Vol 1, 3, January, 1909, p. 10.
} 
The Bean did not shrink from drawing on women's proper feelings of shame in the attempt to construct a community of good, active Irish women. But what of those women who needed no encouraging or cajoling to be active, but instead of using their talents and political motivation for the good of their newly emerging Irish nation, were instead happy to campaign to join the rank and file of the enemy? The Irish woman campaigning for the vote, the Bean said, was a traitor to Ireland. At a time when her country was rising up to take back its liberty, she was asking Ireland's enemy - more embarrassingly, she was pleading with it in fact - to grant her a say in the affairs of an enemy parliament: the British Parliament. She was a woman who was

scrambling for her mess of pottage, and willing to join in with her country’s conquerors and worst enemies to gain her end, but from the point of view of an Irish Nationalist. A woman who knows the truth, knows that in an independent Ireland alone can the men and women who compose the Irish Nation ever hope to find justice and liberty, peace and prosperity. ${ }^{49}$

Campaigning for the freedom of one half of the nation while the other was still in bondage could only be interpreted as extraordinarily selfish. "Do our Nationalist men consider themselves free while Ireland lies in chains?” the Bean continued. Granting British suffrage to Irish women would only mean another chain linking yet another section of the Irish to England. Another confusion of Irish with English ideas. A connection established along which

\footnotetext{
${ }^{49}$ Bean na hEireann, “Correspondence”, Vol. 1, 14, December 1909, p. 13.
} 
the thoughts and interests of the newly awakened women of Ireland are to be carried away to Westminster. ${ }^{50}$

What was the point of awakening the collective consciousness of Irish women, if only England was to gain from that awakening? How could an Irish sisterhood be constructed when women within that group were guilty of consorting with the enemy, thereby selling out their fellow countrymen? As with Britain, it seemed that not only were the nation's most dangerous enemies housed within, but these enemies were the worst for the fact that they were supposed to be the nation's moral keepers. There was more at stake here than the individual woman's reputation: that of Irish womanhood was in jeopardy; the nation itself was at risk.

This reference to unfree nationalist men fighting for Ireland's liberty did not mean that Irishmen were free from shaming in the pages of this radical publication for, of course, Irishmen were already sitting in British Parliament. Indeed, as stated earlier, John Redmond and his Irish Parliamentary Party held the balance of power at Westminster. The plea to Irishmen like Redmond and his party, was to act like proud, independent Irish men and to stand up to Britain. As one writer pleaded: "We need a sterner race, who will not be bribed, bought and sold by England for concessions - messes of Imperial pottage”. ${ }^{51}$ Another rather dramatically asked:

Oh! Men of Ireland, where were you? Were you all asleep? Or getting married? or what? Truly a few women are needed in your ranks, to rouse you from the lethargy which is overtaking you, and both by their example and by competition with their bright intelligence to make you drag yourselves from the slough of indifference into

\footnotetext{
${ }^{50}$ Bean na hEireann, “Correspondence”, Vol. 1, 14, December 1909, p. 13.

${ }^{51}$ Bean na hEireann, "Republicanism in Ireland” by “B.”, Vol. 1, 18, May 1910, pp. 11-12.
} 
which you seem to be slipping...Must it be left to a woman's paper to ask the men of Ireland have they lost all memory of the history of '98? [Referring to the glorious but failed rebellion of the Protestant and Catholic United Irishmen in 1798 $]^{52}$

Apparently, the answer was, yes, it was Irish women’s responsibility. "We shrink from accusing our countrymen of ... slavishness”, another article claimed, indeed, “[t]here is little use in us women starting to abuse men and their methods of thought and action. We must remember the humiliating fact that they are largely what their womenfolk have made them.”53 Women were indirectly responsible for the as yet unsuccessful state of the nationalist movement for they had not performed their duty of inspiring their men. As both the actual and metaphorical mothers of the nation, they had failed to create a "race" of strong, patriotic Irishmen. But the message was clear: they could yet amend that state of affairs.

Whatever the Bean's hesitation about the patriotism of the women of Ireland, its intentions were to inspire or cajole women into being actively involved in the construction not only of a new Irish nationalist identity, but more specifically, in the creation of a new community of good Irish women that traced its lineage back to the national heroines of old. Their primary aim was to draw women back across faultlines that they had temporarily crossed, either into national lethargy (targeting the apathetic) or misled activism (that is, those who campaigned for a foreign vote before national liberation). Unlike Britain’s National League for Opposing Woman Suffrage, the Inghinidhe na hEireann did not believe that the doors of opportunity were fully closed. Irishwomen had not necessarily proved themselves hostile to the Bean's image of an Irish womanhood, simply lethargic. Consequently, they worked to include rather than exclude; to open up a potential community of women, not to emphasise and close its

\footnotetext{
52 Bean na hEireann, “The British Soldier as paying Guest” by Maca, Vol. 1, 7, May 1909, pp. 6-7.

${ }^{53}$ Bean na hEireann, "Editorial Notes”, Vol. 1, 7, May 1909, p. 8; and, Bean na hEireann, "To Our Sisters”, Vol. 1, 3, January 1909, p. 1.
} 
borders. A decent dose of shame was used, then, to motivate and inspire. To have drawn on this technique in the heavy-handed way that British anti-suffragists did would have been counterproductive to the cause of drawing Irish women into the fold. It would have overwhelmed and paralysed, not motivated and mobilised.

\section{Some Final Thoughts}

The multifarious debates over female suffrage taking place in early twentieth-century Britain and Ireland casts light on just how accepted shame and shaming were as political devices in a modern world that was experiencing substantial political upheaval. Whether used to protect an existing group identity or to construct a new one, shame showed that the notion of the communal was still extremely important in a modern society that many asserted was fast becoming individualistic. Shame's connections to the social - the fact that it played on fears about group belonging and identity - meant that it was considered to be not only a particularly apt tool for positive reform but also for protection and exclusion. Reliance on shame as a political technique by female members of the British National League for Opposing Woman Suffrage, for example, exposed a belief in shame’s ability to confirm group boundaries and exclude undesirable elements. But, its simultaneous use by female members of the radical Irish nationalist community also reveals that a healthy dose of shame was also considered to be capable of ushering in positive reform. 